\title{
Quid Pro Quo! Organization Theoretical Remarks about FIFA's Legitimacy Under Blatter and Infantino
}

\author{
${ }^{1}$ Saarland University, Faculty of Human and Business Sciences (HW), Homburg, Saarland, Cermany, E-mail: \\ s8lsrich@stud.uni-saarland.de
}

\begin{abstract}
:
This article addresses the question of the legitimacy of sports organizations, with a particular focus on the football organization FIFA. By applying elements of the public choice theory as well as the concept of political machines to FIFA, we show that the FIFA leadership established an allocation system that works on a discretionary basis in addition to the formal rule-based allocation process. FIFA uses this exchange system to please selected member associations, which in return vote in favor of the leadership's plans and secure its legitimacy. We further illustrate that such a system can only exist in the long run if the majority of both internal and external stakeholders approves the system.
\end{abstract}

Keywords: FIFA, organization theory, political machine, public choice theory, sports economics

JEL classification: L20, L22, Z28

DOI: $10.1515 / \mathrm{ev}-2019-0014$

\section{Diminishing Trust in the Global Football Organization FIFA}

Le roi est mort, vive le roi! Replacing former president Joseph 'Sepp' Blatter with Gianni Infantino in 2016 was supposed to be a fresh start for FIFA after numerous scandals over the previous decade. Corruption in the selection process for the World Cup in Germany (Spiegel Online 2016) and foreigners working under terrible conditions in Qatar to build new stadiums (Liew 2017) are just two examples of scandals that gained considerable public attention and damaged the organization's reputation at the same time. The exhaustive media coverage about these topics also negatively affected public trust ${ }^{1}$ in FIFA and put its integrity and legitimacy into question. However, whether the way FIFA operates has changed since the election of its new president is questionable. From a football fan's perspective, maximizing revenues still seems to be FIFA's ultimate and only objective. FIFA itself clearly describes its role in the football system: According to the official FIFA strategy, its purpose is to "promote the game of football, protect its integrity and bring the game to all" (FIFA 2016, 16).

Existing literature has analyzed football's global governing body from multiple perspectives: One research stream focuses on the motives for corruption and bribery in sports governing bodies such as FIFA (e.g. Bayle and Rayner 2018; Boudreaux, Karahan, and Coats 2016; Jennings 2006, 2011). A second stream, correlated with corruption and bribery, evaluates FIFA's governance, control mechanisms and accountability (e.g. Eisenberg 2006; Meier and García 2015; Pielke 2013; Rowe 2017; Sugden and Tomlinson 1998; Tomlinson 2014; Zeidan and Fauser 2015). A particular focus is drawn on FIFA's historical development and especially the rise of Havelange and his successor Blatter who had a combined tenure as FIFA president of almost half a century (e.g. Sugden and Tomlinson 1997). Further, the increasing political role of African (and Asian) nations since the 1960s is subject to scientific research. This also includes the shifting power within FIFA from a mainly Eurocentric to a more globalized organization with an increasing role of African countries in FIFA's decision-making process (e.g. Cornelissen 2004; Darby 2003, 2005).

On the basis of Jahn (2019), the question arises what actually legitimizes an organization such as FIFA and which factors stabilize the power of the current leadership, with Gianni Infantino at the forefront. Building on the existing literature described above, this study evaluates the legitimacy question from an organization theoretical perspective. We will add to the existing literature by applying elements of the public choice theory and the concept of political machines to FIFA. Moreover, elaborating if FIFA has changed since Infantino took over as president will add to the current scientific and public discussion. 
In line with an evaluation of the IOC (International Olympic Committee) and its decision-making processes by Daumann and Hofmeister $(2012,148)$, the paper at hand applies the theoretical framework to FIFA based on an "empirically tested" approach using anecdotal evidence as the limited number of instances prevents a more sophisticated empirical research.

\section{Organizational Legitimacy and 'the FIFA System'}

According to Forster (2006, 72), monopolistic global sports organizations like FIFA "can be defined as the supreme organs of governance in sport whose authority is global." National associations pool their resources in global organizations such as the IOC or FIFA to represent their interests on a global level. Global organizations then act on behalf of their members by creating and observing global rules and organizing global events (Forster 2006).

Coleman $(1974,757 f$.$) summarizes this construct in general from a theoretical point of view in the follow-$ ing way: "All resources reside in natural persons, and corporate actors ${ }^{2}$ gain their resources through resource investments of one sort or another by natural persons. In doing so, they establish implicitly or explicitly a constitution, which may well be regarded as a social contract among them." In return, a member gets "partial control over the actions of the corporate actor and an expectation of more beneficial consequences [...] than he would have had from his own individual actions (Coleman 1974, 758)." In case of FIFA, the only difference is that its members are associations instead of natural persons.

Regarding FIFA as a resource pool of time, money, knowledge, and social capital that is voluntarily provided by its national members, such a supranational organization must solve three interrelated problems: contributions, delegation of authority by elections, and distribution of resources.

First, resources are provided by members (for example, know-how, social capital, time) and acquired in an international market through the sale of goods. The problem of distribution concerns the allocation of resources among national members and the authorities of the organization in such a way that personal and corporate members' expectations are met over the long term and not disappointed. However, the monopoly structure of FIFA prevents national members from choosing to exit the organization (cf. Hirschman 1970): if they want to take part in world championships, they have to stay. Finally, the problem of delegation pertains to the allocation of power within the supranational organization and the delegation of authority through its elections.

The delegation problem must be solved before the contribution and distribution problems can be addressed, because the members of the executive board are elected at the general meeting. After being elected, the executive board members decide on the production and distribution of goods or services. So the election of the executive board members can be seen as a trust-based delegation of authority, because the expected distribution of resources in the future is very important. So, a trust-based exchange occurs between a member's vote and future chances to participate in the consumption of the income of the supranational organization, produced mainly by its national members' athletes (cf. an institutional economic perspective on the International Olympic Committee in Emrich and Pitsch 2011). This exchange must be organized in a way such that the expectations of voters are met over the long run (for sports clubs, see Gassmann, Emrich, and Pierdzioch 2017).

In recent years, sports clubs and organizations such as FIFA have experienced a considerable professionalization, paving the way for increasing revenues. What still differentiates sports organizations and especially football clubs from traditional profit-seeking companies are the roots they are built on. As indicated above, organizations rely on common rules and values. Therefore, sports organizations operate both in an environment of communitarization and in an environment of market orientation (Heinemann 2007, 143). Often the analogy of 'a family' is used to explain the communitarization concept (e.g. Emrich, Gassmann, and Koch 2019). While the feeling of being 'a family' bears the risk of having elections that only appear as democratic (Emrich, Gassmann, and Koch 2019), stronger market orientation and higher revenue potential further fuel the conflict between these two dimensions.

FIFA, in particular, is a global body with 211 member associations (FIFA 2019). As a global umbrella, FIFA holds the World Cup and negotiates marketing and broadcasting rights with its partners and sponsors. FIFA's income mainly derives from television broadcasting, marketing, and licensing rights. On the cost side, FIFA spends most on "development \& education" and "competitions \& events" as shown in the official financial report (FIFA 2017, 19). FIFA works according to the rules of a registered club and the disclosure of its financial situation, in the sense of a balance sheet, is voluntary.

From an organization theory perspective, FIFA's revenue allocation process to its member associations includes both rule-based allocations and discretionary budgets. Examples of rule-based budgets are the prize money and compensation paid to the clubs for every player they send to official tournaments, as well as, for example, a considerable expense allowance for the members of the executive board. Prize money and compen- 
sation are determined upfront and are paid based on the teams' performance, resulting in a transparent and reliable process. On the other hand, there are also financial resources (e.g. for projects and TV rights) that can be allocated on a discretionary basis; these are an attractive vehicle to provide member associations or executives with benefits outside the rule-based allocation process. Projects for which variable grants may be awarded at the request of members are an example. Emrich, Pierdzioch, and Rullang (2013) evaluate the effect of rule-based budgets and those with discretionary power in the context of subsidies to German elite sports, which forms the basis for the following application to FIFA.

From the perspective of the FIFA leadership, the ultimate objective is to maximize its own consumption after having sufficiently satisfied its members, which ensures the legitimacy of the FIFA leadership (for the leadership of the IOC as an optimizing dictatorship, see Pierdzioch, Emrich, and Klein 2014). In this context, the consumption of the leadership is best represented by tenure in the office, which is accompanied by associated benefits, such as a positive reputation. The formal legitimacy by the FIFA Congress, consisting of all member associations, takes place every 4 years at the presidential election (FIFA 2018, 32). At the same time, the election represents a type of indirect control (Vanberg 1979, 116). Besides this internal process, other stakeholders, like sponsors and fans, provide the external legitimacy (cf. the influence of integrity on sponsorship activity in Kulczycki and Koenigstorfer 2016).

In general, sports organizations such as FIFA are especially in danger of corruption due to the increasing market orientation and the lack of powerful control bodies (see Emrich, Gassmann, and Koch 2019 for a more detailed description). For FIFA in particular, as the selection process for World Cup hosts and the election of the FIFA president are rather opaque, 'behind-the-scene' actions (see Goffman 1956) in order to influence the outcomes for different stakeholders in different ways are possible. In order to secure its authority, the leadership can therefore leverage the revenue allocation process to get the required support by a critical mass of members. The means to get the support of selected members are not limited to financial grants but can take other forms, such as increasing the number of participants at the World Cup, which particularly helps nations not ranked among the top teams. Since all member association votes at the presidential election are equal, it is particularly attractive to offer these grants to poorer members. Especially the African and Asian confederations, which consist of many small associations with little financial resources and little chance to ever qualify for the World Cup with a cap of 32 participants, are attractive for financial and non-financial grants (cf. Persson, Rothstein, and Teorell 2013 regarding systemic corruption as a collective action problem).

As a global sports governing body, FIFA's role is also highly relevant from an economic perspective, as FIFA functions as an essential player in re-distributing money from First World countries to the Third World. FIFA's objective of "making the world a better place" by supporting less developed countries highlights this role (FIFA $2005,1)$.

With more countries joining FIFA, the influence of major European federations such as England and Germany continually decreases. Table 1 shows FIFA's member associations per confederation as of 2019 in absolute terms as well as their relative share. As shown in Table 1, the bloc of (rather poor) African (CAF) and Asian (AFC) countries within FIFA counts for almost 50 percent of the total votes and thus makes up a considerable power in the decision-making process. Analyzing past elections, Darby $(2003,3)$ states that Africa was "the key electoral constituency in the struggles for the FIFA presidency in 1974, 1998, and 2002". While there were 143 associations when Blatter's predecessor, Joao Havelange, took over FIFA presidency in 1974, the number increased to 211 members as of today with mainly developing countries joining the FIFA since 1974. This power shift in the decision-making process in the past decades underlines why the before mentioned grants to poor associations such as African and Asian members are so attractive from FIFA's leadership perspective to secure its position.

Table 1: FIFA associations per confederation as of 2019a

\begin{tabular}{llrr}
\hline Confederation & Region & $\mathbf{2 0 1 9}$ \\
\cline { 3 - 3 } & & Absolute & Relative \\
\hline UEFA & Europe & 55 & $26.1 \%$ \\
CAF & Africa & 54 & $25.6 \%$ \\
AFC & Asia & 46 & $21.8 \%$ \\
CONCACAF & North and Central America and Caribbean & 35 & $16.6 \%$ \\
OFC & Oceania & 11 & $5.2 \%$ \\
CONMEBOL & South America & 10 & $4.7 \%$ \\
& Total & 211 & $100 \%$ \\
\hline
\end{tabular}

a Based on https://www.fifa.com/associations/. 
The past decades have demonstrated that FIFA uses an unofficial exchange system. FIFA's leadership provides selected members and executives with grants to please them. In return, the favored association guarantees its support for the plans of FIFA. This 'quid pro quo'-system works on reciprocity and has secured and still secures the legitimacy of FIFA's leadership and FIFA as a whole in its current structure (for more on reciprocity, see Gouldner 1959; for more on corruption cf. Kihl, Skinner, and Engelberg 2017). Interestingly, while resource pooling by multiple member associations in sports organizations usually eliminates the need for bilateral 'give and get-deals' (Vanberg 1979, 104), FIFA managed to establish exactly such a bilateral system in addition to a common profit pool. The most prominent example of this exchange system for German football fans is probably the selection of Germany as the World Cup host for 2006.

Public criticism mainly focused on Blatter in the past. However, already Blatter's predecessor, Joao Havelange, has focused on the support from the African and Asian voting blocs during his time as FIFA president from 1974 to 1998 (Edwards 2016). With regard to the electoral campaign 1974, Patrick Nally noted: “No sports president had ever gone round the world glad-handing and campaigning" as Havelange did (Simson and Jennings 1992, 39f.). Thus, Blatter, who was already FIFA's general secretary under Havelange, did not invent the 'quid pro quo'-system but rather managed to optimize the process by an ongoing globalization of football beyond Europe and South America (Szymanski 2015). Further actions to get support were the allocation of the World Cup to the Asian and African confederations - the World Cups 2002 (South Korea/ Japan) and 2010 (South Africa) were the first on the respective continents - that provided FIFA's leadership at that time with additional support (BBC 2015a).

In case of FIFA, especially the role of long-time sponsors such as Adidas and Coca Cola needs to be stressed. Sponsorship deals with transnational companies such as Adidas and Coca Cola (with particular help from Horst Dassler ${ }^{3}$ ) provided Joao Havelange with the required financial resources to keep the promises he made ahead of the 1974 election and enabled him to establish the 'quid-pro-quo'-system in the first place (e.g. Sugden and Tomlinson 1997; Darby 2003). As Jennings (2006) pointed out, Adidas - in person of Horst Dassler - was one of the main drivers in putting Blatter at the forefront. Later, key sponsors such as those two companies enabled Blatter to expand the 'quid-pro-quo'-system.

In light of an ongoing commercialization under Havelange and Blatter, FIFA's revenues started to flourish. Thereby, FIFA faced similar challenges as other sport governing bodies such as the IOC: While FIFA developed from a 'family' to a more market and revenue-oriented enterprise, FIFA failed to adjust its governance according to the new requirements, which opened the door for 'behind-the-scene' actions and direct bribery (Pielke 2013; Tomlinson 2014). Instead, FIFA established an "autocratic leadership" (Tomlinson 2014, 1160) under Havelange that Blatter further manifested when taking over presidency in 1998.

As FIFA's leadership relies on the confirmation of its power via elections, it is of interest if FIFA's leadership shows some cyclical behavior as elections approach. In a general political context, Nordhaus (1975) evaluates if politicians behave differently at the beginning of their term compared to the behavior at the end. An essential requirement for cyclical behavior is that the leadership has control over financial resources and other political measures so that they can enforce the political change to influence the voters' behavior (cf. Nordhaus 1975 for more details on political business cycles). Applied to FIFA, some cyclical behavior is observable from past elections: For example in 2011, Blatter promised to allocate $\$ 1$ billion to the development fund in case of his reelection (Kelso 2011). However, these seem to be rather supplementary actions in order to gain positive public recognition as the election approaches. The main pattern to keep power at FIFA is rather a constant support than a cyclical behavior. Therefore, Havelange and Blatter constantly traveled the globe to visit especially smaller associations and provided support for development projects to maintain their loyalty.

As a reason for cyclical behavior, Nordhaus suggests a limited memory horizon by voters, i.e. that voters are more concerned about the most recent behavior of politicians. In case of FIFA (and in particular the case of Blatter), rather the contrary of a voters' limited memory horizon seems to prevail. Based on the constant allocation of particular benefits during Blatter's entire reign, many national associations, especially from Asia and Africa, continued supporting Blatter despite all corruption allegations before the elections showing great loyalty to Blatter. Even controversial statements made by the president are offset by financial grants and other benefits to its member associations (e.g. see New York Times Online 2015 for Blatter's statements about racism in football, potential homosexuality issues during the upcoming World Cup in Qatar and women's soccer). However, using financial grants is only possible for the incumbent with the control over the financial resources and a considerable influence on the World Cup host selection process, which gives him an advantage over any challenger. The length of Havelange's (24 years) and Blatter's (17 years) presidencies further illustrate this advantage.

A further issue besides the discretionary allocation process concerns direct bribes that are especially likely in case of weak control mechanisms as described above. For multiple decades now, FIFA's presidential elections are accompanied by rumors of direct bribes, which the candidates allegedly used to change the voters' opinion in their favor. Due to the voting system of one vote per country, the heads of the member associations are 
especially attractive for bribery. Other sports governing bodies such as the IOC face similar accusations in its selection process for major sports events such as the Olympic Games (Daumann and Hofmeister 2012, 168ff). Criticism concerns for example FIFA's development fund: Allegedly, part of the money from the development fund does go directly to officials in the national associations while only the remainder is invested according to the original purpose into infrastructure and national football projects (Voss 2015).

Thus, the combination of the voting procedure 'one country, one vote' and the constant feeding (legal and illegal) of influential voting blocs such as the African and Asian countries by the incumbent, helped Blatter and Havelange to maintain their power.

For an organization such as FIFA, however, allocating money using its discretionary power is a doubleedged sword. Those processes can only be sustained up to a point where FIFA's legitimacy is not endangered. Therefore, FIFA must ensure that more than half of its members approve the allocation process and its outcome. Furthermore, the majority of unsatisfied members should alternate from year to year to keep the number of constantly unsatisfied members in the minority (Emrich, Pierdzioch, and Rullang 2013).

Overusing discretionary budgets is especially risky, as an organization such as FIFA relies on stable and reliable rules. All members must accept these rules in order to provide a stable environment for financial investors, commercial partners, and other stakeholders. Opaque rules can lead to a vicious circle, with a lack of investors and sponsors resulting in lower revenues and consequently a smaller budget to allocate on a discretionary basis, which can ultimately endanger FIFA's legitimacy. Some resistance among FIFA's sponsors has been observable in the past years. While traditionally Western companies accounted for most of the sponsorship deals, some of those companies have been more hesitant in cooperating with FIFA due to the ongoing corruption investigations. Instead, firms such as Gazprom (Russia), Wanda (China) and Qatar Airways (Qatar) took their place. This shift demonstrates that FIFA puts its objective of revenue maximization above potential democracy concerns in the sponsors' home countries (i.e. partly autocratic structures) (Nufer 2018). Although four companies (Visa, Coca Cola, McDonald's, Anheuser-Busch InBev) publicly demonstrated their criticism by calling for Blatter's resignation in 2015 (Das 2015), the majority of the sponsors continuously supports FIFA and thereby legitimizes its (new) leadership. Especially the long-time sponsors, Adidas and Coca Cola, that supported the system Havelange/ Blatter from the beginning, are still among the most important FIFA sponsors (so-called "FIFA Partners"), which underlines that the benefits for such sponsors still seem to exceed the potential reputational damage.

For comparison, Emrich, Pierdzioch, and Pitsch $(2014,105 \mathrm{ff})$ have evaluated the IOC as an optimizing entrepreneur. For the IOC, the utility function consists of consumption and power. They describe the income of sports governing bodies such as the IOC (also applicable to FIFA) as a function of sports activities and power of the IOC. The more power the IOC has, the better it can negotiate asymmetric contracts with sponsors and tournament hosts (i.e. higher income for the IOC). Emrich et al. further elaborate that the IOC's power is not given by nature, but depends on the customers' loyalty while loyalty is the result of two aspects: 1) investments into the appearance of honesty and 2) the IOC's "impression management". Therefore, organizations such as the IOC and FIFA face an optimization problem as investments in the investigation of unethical behavior increase the number of cases that become public. On the one hand, these investments increase loyalty, while numerous unethical behavior will decrease loyalty ${ }^{4}$. Therefore, it is in FIFA's interest to invest in the investigation of unethical behavior such as corruption to the extent that it does not negatively affect its revenue basis.

Thus, FIFA faces a trade-off between the use of its discretionary power and a certain measure of transparency in its allocation process. In other words, securing its legitimacy with a 'quid pro quo'-system comes at the risk of a negative public reputation when corruption or shady deals become public (for a game theory perspective of such a problem, see Büchel, Emrich, and Pohlkamp 2016).

With its organizational structure including a clear hierarchy and its internal processes, FIFA resembles a political machine as known from other (historical) political organizations. A fundamental pre-requisite for the existence of a political machine is the presence of an election that requires all candidates to accumulate enough votes to be elected for a leadership position (Scott 1969). Scott $(1969,1144)$ - based on Banfield and Wilson (1963) - defines political machines as "a non-ideological organization interested less in political principle than in securing and holding office for its leaders and distributing income to those who run it and work for it." In the past decades, FIFA seems to have become a political machine: With Havelange, Blatter and now Infantino at the forefront, there were clear leaders with the objective of getting re-elected irrespective of political principles but rather driven by the constant use of discretionary power to get enough votes. Thereby, voters are only concerned with the concrete benefits FIFA's leadership can provide. Thus, the previously described 'quid pro quo'-system between FIFA's leadership and the voting member associations as well as other stakeholders keeps the political machine running. As political machines work best when poverty is prevalent (Banfield and Wilson 1963), the dominance of poor member associations from Africa and Asia further helps the persistence of FIFA as a political machine. Similar to FIFA's conflict between the (wealthy) Eurocentric voting bloc with a long football history and the new (rather poor) Third World voting bloc, past political machines have often caused 
conflicts with other groups not so prone for financial inducements. Moreover, the existence of political machines is necessarily associated with corruption - an issue also FIFA's leadership is (allegedly) constantly involved in as shown in the previous paragraphs. Corruption as in FIFA's case can take two forms: active corruption by FIFA's leadership as well as (passive) tolerance of corruption within the system (based on Scott 1969).

While shady and even illegal deals, as well as opaque selection processes, have already diminished fans' trust in FIFA, revenue growth reduces the risk that member associations and other stakeholders, such as main sponsors, will start questioning the legitimacy of FIFA. As long as all members benefit from financial growth, they will not question the system and the political machine will continue to exist. Even though fans may criticize processes, adverse effects on football consumption have yet to occur (Jahn 2019).

Consequently, the perceived reality determines if members continue to approve the allocation process, including rule-based budgets and discretionary budgets. As previous studies on income inequality have shown, actual and perceived differences can differ considerably (e.g. Hauser and Norton 2017). Especially in case of the allocation of non-monetary benefits, a fair allocation can be challenging (Vanberg 1979, 107). Additionally, there is no objective criterion to evaluate if FIFA operates successfully. Is it maximizing revenues or fan attendance at the World Cup? Or something of a qualitative nature, such as fan satisfaction?

\section{The Gianni Infantino Era}

In 2015, with the FBI investigating leading members of the FIFA Council, including its president, Joseph Blatter, trust in the organization reached an all-time low, endangering the legitimacy of FIFA. At this point, the accusations against Blatter and his colleagues got too serious to keep him in office (BBC 2015b). Therefore, Gianni Infantino, the former general secretary of the European association UEFA and member of the FIFA network, was elected as his successor. Infantino started his presidency - in what really was no surprise - by actively supporting all investigations and reforming FIFA to ensure its legitimacy.

Despite the reform, which instituted a formal distribution of power, Infantino is still the one who decides on the most important positions. Overall, Infantino's role is ambivalent: he acts like a democrat to the public and the FIFA Congress when agreeing to reform on the front stage; at the same time, he still has all the means at hand to rule as a king and to remain untouchable on the back stage. A first example of the latter was the replacement of both leaders of the FIFA ethics committee (Fritsch 2018).

Public opinion is that nothing has changed following the handover from Blatter to Infantino. Some argue that things have even gotten worse. Ironically, at a time of severe moral doubts about FIFA, one of Infantino's promises before his election was to generate higher returns for the member associations, underlining the focus on revenues and profits irrespective of all ongoing ethical discussions (Kopp 2018). Moreover, FIFA under Infantino still uses non-rule-based budgets to secure its legitimacy: in order to generate additional revenues from the Middle East and to secure his re-election in 2019, last year Infantino suggested that one of Qatar's neighbors could cohost the World Cup in 2022 while increasing the number of participants from 32 to 48 (Kopp 2018). Thereby, the promise of increasing the number of World Cup participants to please small associations is not new, but rather an adapted promise from Havelange's playbook (Sugden and Tomlinson 1997).

However, resistance from the inside is growing. The European association UEFA and large associations like the one in Germany have increasingly criticized the president, which should be a warning sign for FIFA's leadership not to overuse opaque processes to secure its power (Fritsch 2018). How the organization positions itself on the continuum of communitarization and market orientation in the coming years will be decisive for the cohesion of FIFA. But as long as the fundamental problem of the influence of the national organizations remains, namely one vote per nation, this situation will not change, and in order to change this rule, those who benefit from it would also have to agree. Thus, if the political machine continues to exist (i.e. FIFA's leadership continues to satisfy the needs of major voting blocs such as Africa and Asia), a change of the current system is very unlikely.

It is not really surprising, but for the latest election of the new FIFA president, Infantino was the only candidate. Similarly, sponsors and partners are still willing to invest in FIFA projects and events, which seems like an ongoing external legitimization of FIFA from the investors' side (for organizing anti-corruption, cf. Lambsdorff 2009). In a nutshell, while the players might have changed, the game has not!

\section{Concluding Remarks}

To combat corruption, FIFA has tried in recent years to establish rules of conduct (e.g. the Code of Ethics) and to monitor them (Gardiner, Parry, and Robinson 2017). Reform strategies have been announced and partly 
initiated, ethics committees have been set up (also dismissed, as in Zeit Online 2017), educational programs have been drawn up, and regulations and penalties have been tightened (cf. Kihl, Skinner, and Engelberg 2017).

At the level of the leadership of sports organizations, past mistakes have resulted in research into the concepts of good governance, corporate governance, and corporate social responsibility in order to examine the transfer of problem solutions from 'the real economy' to sports. Indicators such as transparency, democracy, social responsibility, mutual control, equal treatment, and diversity have been mentioned (Geeraert 2016, 57f.) in order to evaluate and compare the quality of the management of sports organizations. In addition, there is intensive involvement with ethical questions of sport.

Other research approaches, based on the Principal-Agent theory (for sports governance, cf. Geeraert 2016), could show that trust and a sense of community are conducive conditions for the wide range of financial decision-making leeway in sports clubs and low control activities: above all, trust is an essential factor in corrupt relationships and therefore a central aspect in associated studies. In this context, the problem of the iron law of the oligarchy (Michels 1915), which favors Old Boys Networks and for which the type of voluntary organization is particularly receptive, cannot be overlooked.

These approaches usually only address individual components of the fight against corruption. Reports about their effectiveness cast doubt on the seriousness of such measures (cf. Gardiner, Parry, and Robinson 2017), as there are no signs of corruption having been curbed. Either the reforms do not fit in with the structure of the individual organizations (cf. Pielke 2013) or the will for serious change does not exist but is merely communicated, as a kind of Cheap Talk (Farrell and Rabin 1996).

Focusing on FIFA in this article, FIFA is by no means the only global or national organization facing doubts about its legitimacy. UEFA and even the German DFB/ DFL are just two additional examples. In the case of the German Football Association, there is a constantly increasing gap between professional football and the amateur leagues. UEFA faces criticism with regard to the handling of its Financial Fairplay regulation: while small teams are severely penalized, other teams with potentially better marketing potential are exempted. The name of the UEFA official who allegedly helped two teams to avoid penalties for breaking Financial Fairplay rules: Gianni Infantino (Fritsch 2018)!

\section{Notes}

1 In a recent study, Waschbusch, Schuster, and Berg $(2018,29$, translated) define trust as a "psychological state (confidence expectation) of a decision-maker (trust-giver) that expresses a positive expectation in the behavior, the intentions or the function of persons or systems (trustee) and leads to a voluntary provision of a risky advance (act of trust) [...]"

2 A term used by Coleman for organizations.

3 Tomlinson 2014.

4 See Emrich, Pierdzioch, and Pitsch (2014) for more details on the model describing the IOC as an optimizing entrepreneur.

\section{References}

Banfield, Edward C., and James Q. Wilson. 1963. City Politics (1st ed.). Cambridge, MA: Harvard University Press and the M.I.T. Press. Bayle, Emmanuel, and Hervé Rayner. 2018. "Sociology of a Scandal: the Emergence of 'FIFAgate'." Soccer and Society 19 (4): 593-611. BBC. 2015a. “FIFA Election: Sepp Blatter and Prince Ali Battle for Power.” BBC Sport Online. May 29. https://www.bbc.com/sport/football/32925307.

BBC. 2015b. “FIFA Corruption Crisis: Key Questions Answered.” BBC News Online. December 21. https://www.bbc.com/news/world-europe32897066.

Boudreaux, Christopher ]., Gokhan Karahan, and Morris Coats. 2016. “Bend it Like FIFA: Corruption on and off the Pitch." Managerial Finance 42 (9): 866-878.

Büchel, Berno, Eike Emrich, and Stefanie Pohlkamp. 2016. “Nobody's Innocent: The Role of Customers in the Doping Dilemma." Journal of Sports Economics 17 (8): 767-789.

Coleman, James S. 1974. "Inequality, Sociology, and Moral Philosophy." American Journal of Sociology 80 (3): 739-764.

Cornelissen, Scarlett. 2004. "It's Africa's Turn! The Narratives and Legitimations Surrounding the Moroccan and South African Bids for the 2006 and 2010 FIFA Finals." Third World Quarterly 25 (7): 1293-1309.

Darby, Paul. 2003. "Africa, the FIFA Presidency, and the Covernance of World Football: 1974, 1998, and 2002." Africa Today 50 (1): 3-24.

Darby, Paul. 2005. "Africa and the 'World' Cup: FIFA Politics, Eurocentrism and Resistance." The International Journal of the History of Sport 22 (5): 883-905.

Das, Andrew. 2015. “Coca-Cola, Visa, McDonald's and Anheuser-Busch Call on FIFA's Sepp Blatter to Resign.” The New York Times. October 2. https://www.nytimes.com/2015/10/03/sports/soccer/sepp-blatter-coca-cola-mcdonalds-fifa-resign.html.

Daumann, Frank, and Hannes Hofmeister. 2012. “Die Vergabe der Olympischen Spiele Durch das IOC - Eine Institutionenökonomische Analyse." In Zur Ökonomik von Spitzenleistungen im internationalen Sport, edited by Martin-Peter Büch, Wolfgang Maennig, and HansJürgen Schulke, 147-193. Hamburg: Hamburg University Press. 
Edwards, Piers. 2016. "Joao Havelange, the Unlikely Codfather of African Football.” BBC News Online. August 19. https://www.bbc.com/news/world-africa-37120388.

Eisenberg, Christiane. 2006. "FIFA 1975-2000: The Business of a Football Development Organisation." Historical Social Research 31 (1): $55-68$. Emrich, Eike, and Werner Pitsch. 2011. Sport and Doping. The Analysis of an Antagonistic Symbiosis. Frankfurt am Main: Lang.

Emrich, Eike, Christian Pierdzioch, and Christian Rullang. 2013. "Zwischen Regelgebundenheit und diskretionären Spielräumen: Die Finanzierung des bundesdeutschen Spitzensports." Sport und Gesellschaft 10 (1):3-26.

Emrich, Eike, Christian Pierdzioch, and Werner Pitsch. 2014. "Die "Marke" Olympia und die besondere Bedeutung von Vertrauenskriterien - Eine Ceschichte von Markt, Macht und Moral," In Leistungssport als Konkurrenz der Nationen - Sozioökonomische Bedingungen und Effekte, edited by Jan Haut, 89-116. Saarbrücken: universaar.

Emrich, Eike, Freya Gassmann, and Michael Koch. 2019. "Korruption im Sport als spezielle Organisationsform zwischen Vormoderne und Rationalität." Jahrbuch Aufgang. Forthcoming.

Farrell, Joseph, and Matthew Rabin. 1996. “Cheap Talk.” The Journal of Economic Perspectives 10 (3): 103-118.

FIFA. 2005. "Make the World a Better Place: Mission, Coals and Programmes of the FIFA Football for Hope movement." http://www.fifa.com/mm/document/afprograms/worldwideprograms/fifa_ffh_en_1851.pdf.

FIFA. 2016. “FIFA 2.0: The Vision for the Future.” October 13. https://resources.fifa.com/mm/document/affederation/generic/02/84/35/01/FIFA_2.0_Vision_LO

FIFA. 2017. "Financial Report 2017." https://resources.fifa.com/image/upload/fifa-financial-report2017.pdf?cloudid=nyjyxrod7fuwlyzzdokw.

FIFA. 2018. "FIFA Statutes." August. https://resources.fifa.com/image/upload/the-fifa-statutes-2018.pdf?cloudid=whhncbdzio03cuhmwfxa. FIFA. 2019. "Associations and Confederations." https://www.fifa.com/associations/.

Forster, John. 2006. "Clobal Sports Organisations and Their Governance." Corporate Covernance: The International Journal of Business in Society 6 (1): 72-83.

Fritsch, Oliver. 2018. “Cianni Infantino: Noch schlimmer als Sepp Blatter." Zeit Online. November 6. https://www.zeit.de/sport/2018-11/gianniinfantino-sepp-blatter-fifa-praesident-football-leaks.

Gardiner, Simon, Jim Parry, and Simon Robinson. 2017. “Integrity and the Corruption Debate in Sport: Where is the Integrity?" European Sports Management Quarterly 17 (1): 6-23.

Gassmann, Freya, Eike Emrich, and Christian Pierdzioch. 2017. “Sportvereinsforschung aus Sicht des Methodologischen Individualismus." In Beiträge zur Lehre und Forschung im Sport: Vol. 192. Der Sportverein. Versuch einer Bilanz, edited by Lutz Thieme, 479-503. Schorndorf: Hofmann.

Geeraert, Arnout. 2016. The EU in International Sports Governance. A Principal-Agent Perspective on EU Control of FIFA and UEFA. London: Palgrave Macmillan.

Coffman, Erving M. 1956. The Presentation of Selfin Everyday Life. Edinburgh: University of Edinburgh, Social Sciences Research Centre.

Couldner, Alvin W. 1959. "Reciprocity and Autonomy in Functional Theory." In Symposium on Sociological Theory, edited by Llewellyn Cross, 241-270. Evanston, III.: Row, Peterson.

Hauser, Oliver P., and Michael I. Norton. 2017. “(Mis) Perceptions of Inequality.” Current Opinion in Psychology 18 (1): 21-25.

Heinemann, Klaus. 2007. Einführung in die Soziologie des Sports (5. Ed.). Schorndorf: Hofmann.

Hirschman, Albert Otto 1970. Exit, Voice and Loyalty. Responses to Decline in Firms, Organizations and States. Cambridge, MA: Harvard University Press.

Jahn, Johannes. 2019. "Sind FIFA und UEFA legitime Organisationen?" WiSt-Wirtschaftswissenschaftliches Studium 48 (2-3): 1.

Jennings, Andrew. 2006. Foul! The Secret World of FIFA: Bribes, Vote Rigging and Ticket Scandals (1. Ed.). London: HarperSport.

Jennings, Andrew. 2011. "Investigating Corruption in Corporate Sport: The IOC and FIFA." International Review for the Sociology of Sport 46 (4): 387-398.

Kelso, Paul. 2011. “FIFA president Sepp Blatter launches Re-Election Manifesto Promising \$1 Billion Handout to Voting Members." The Telegraph. April 21. https://www.telegraph.co.uk/sport/football/international/8463230/Fifa-president-Sepp-Blatter-launches-re-electionmanifesto-promising-1-billion-handout-to-voting-members.html.

Kihl, Lisa A., James Skinner, and Terry Engelberg. 2017. “Corruption in Sport: Understanding the Complexity of Corruption." European Sport Management Quarterly 17 (1): 1-5.

Kopp, Johannes. 2018. "Fifa-Chef Cianni Infantino: Alles außer Kontrolle.” Taz, Die Tageszeitung. December 29. http://www.taz.de/!5562126/.

Kulczycki, Wojciech, and Joerg Koenigstorfer. 2016. “Why Sponsors should Worry about Corruption as a Mega Sport Event Syndrome." European Sport Management Quarterly 16 (5): 545-574.

Lambsdorff, Johann Craf 2009. "The Organization of Anti-Corruption: Cetting Incentives Right," In Corruption, Global Security, and World Order, edited by Robert I. Rotberg, 389-415. Washington, D. C.: Brookings Institution Press.

Liew, Jonathan. 2017. “World Cup 2022: Qatar's Workers are Not Workers, they are Slaves, and they are Building Mausoleums, Not Stadiums." Independent Online. October 3. https://www.independent.co.uk/sport/football/international/world-cup-2022-qatars-workersslaves-building-mausoleums-stadiums-modern-slavery-kafala-a7980816.html.

Meier, Henk E., and Borja Carcía. 2015. “Protecting Private Transnational Authority Against Public Intervention: Fifa's Power Over National Governments." Public Administration 93 (4): 890-906.

Michels, Robert. 1915. Political Parties: A Sociological Study of the Oligarchical Tendencies of Modern Democracy. New York: Hearst's International Library Co.

New York Times. 2015. “The Rise and Fall of Sepp Blatter.” The New York Times Online. December 21. https://www.nytimes.com/interactive/2015/05/27/sports/soccer/sepp-blatter-fifa-timeline.html.

Nordhaus, William D. 1975. “The Political Business Cycle.” Review of Economic Studies 42 (2): 169-190.

Nufer, Gerd. 2018. “China, Katar und Russland - Die neuen FIFA-Geldgeber: Hauptsache der Rubel rollt weiter!” Focus Online. June 18. https://www.focus.de/sport/experten/nufer/fifa-geldgeber-china-katar-und-russland-hauptsache-der-rubel-rollt_id_9114957.html.

Persson, Anna, Bo Rothstein, and Jan Teorell. 2013. "Why Anticorruption Reforms Fail - Systemic Corruption as a Collective Action Problem." Covernance 26 (3): 449-471. 
Pielke, Roger. 2013. “How can FIFA be held Accountable?" Sport Management Review 16 (3): 255-267.

Pierdzioch, Christian, Eike Emrich, and Markus Klein. 2014. "Die optimierende Diktatur - Politische Stabilisierung durch staatlich verordnetes Doping am Beispiel der DDR." Vierteljahrschrift für Sozial- und Wirtschaftsgeschichte 101 (1): 23-48.

Rowe, David. 2017. "Sports Journalism and the FIFA Scandal: Personalization, Co-optation, and Investigation." Communication and Sport 5 (5): 515-533.

Scott, James C. 1969. “Corruption, Machine Politics, and Political Change.” The American Political Science Review 63 (4): 1142-1158.

Simson, Vyv, and Andrew Jennings. 1992. The Lords of the Rings - Power, Money and Drugs in the Modern Olympics (1. Ed.). London: Simon and Schuster.

Spiegel Online. 2016. “Vergabe der WM 2006-Ceschichte eines Skandals.” Spiegel Online. September 1. http://www.spiegel.de/sport/fussball/chronologie-des-skandals-um-die-wm-vergabe-2006-a-1110419.html.

Sugden, John, and Alan Tomlinson. 1997. "Clobal Power Struggles in World Football: FIFA and UEFA, 1954-74, and their Legacy." International Journal of the History of Sport 14 (2): 1-25.

Sugden, John, and Alan Tomlinson. 1998. "Power and Resistance in the Covernance of World Football." Journal of Sport \& Social Issues 22 (3): 299-316.

Szymanski, Stefan. 2015. “How FIFA can Find a New Direction and Start the Clean-Up of Corruption.” The Guardian. May 30. https://www.theguardian.com/football/2015/may/30/fifa-new-direction-corruption-sepp-blatter.

Tomlinson, Alan. 2014. "The Supreme Leader Sails on: Leadership, Ethics and Governance in FIFA." Sport in Society 17 (9): 1155-1169.

Vanberg, Viktor. 1979. “Nachwort: Colemans Konzeption des korporativen Akteurs - Crundlegung einer Theorie sozialer Verbände." In Macht und Cesellschaftsstruktur by James S. Coleman, 93-123. Tübingen: J.C.B. Mohr (Paul Siebeck).

Voss, Markus. 2015. “Die FIFA gibt, die FIFA nimmt - So machte Blatter den Weltfußballverband zur Geld-Maschine." Focus Online. 28 May. https://www.focus.de/finanzen/news/die-fifa-gibt-die-fifa-nimmt-so-machte-blatter-den-weltfussballverband-zur-geldmaschine_id_4712449.html.

Waschbusch, Gerd, Hannes Schuster, and Susen C. Berg. 2018. Banken und Vertrauen. Eine Grundlagenuntersuchung zur Bedeutung des Vertrauens in der Ökonomie am Beispiel des Kreditgewerbes. Baden-Baden: Nomos.

Zeidan, Obada S., and Simon G. Fauser. 2015. “Corporate Governance and Corporate Social Responsibility: The Case of FIFA." Problems and Perspectives in Management 13 (2): 183-192.

Zeit Online. 2017. “Fifa: Führung der Ethikkommission wird abgesetzt." Zeit Online. May 9. https://www.zeit.de/sport/2017-05/fifaethikkommision-joachim-eckert-entlassen. 